\title{
Pilomatricoma Localized in the Arm: A Rare Case Report
}

\author{
Emin Özkul, Mehmet Onur Ziyadanoğulları*, Mehmet Fırat Tantekin and Serhat Elçi \\ Department of Orthopaedics and Traumatology, Dicle University Medical Faculty, Diyarbakir, Turkey
}

Received: 眥 May 07, 2018; Published: 眥 May 15, 2018

*Corresponding author: M Onur Ziyadanoğulları, Orthopaedic surgeon, Dicle University Medical Faculty, 21280, Diyarbakir, Turkey

\begin{abstract}
A pilomatricoma is a rare, benign skin tumour originating from the hair follicle cells. It accounts for 0.15 of skin tumours is. It usually involves the head and neck region. The definitive diagnosis is based on histological examination. The recommended treatment is surgical removal of the lesion. Herein, we report a 40-year-old male case of pilomatricoma localized in the arm. We present our case due to its rare occurrence in the arm.
\end{abstract}

\section{Introduction}

Pilomatricoma was first defined by Malherbe and Chenantais in 1880. It is a rare benign soft tissue tumour which is originated from varying stem cells of hair follicles. Earlier, it was known as the calcifying epithelioma of Malherbe and named as pilomatricoma by Forbis and Helwig in 1961[1,2]. The tumour is usually localized under the skin with a slowly growing pattern and presents with firm and and mobile masses. It can be seen as a single nodule; however, multiple pilomatricomas have been also reported $[3,4]$. More than one lesion can be seen with a ratio of 2 to $10 \%$. Also, malignant forms have been reported. This malignant form is named as Pilomatrix carcinoma and has been shown to metastatize to the lung, bone, brain, skin, lymph nodes, and abdominal organs [5-8]. Pilomatricomas can be seen in women under 20 years of age, particularly, compared to men in a ratio of 3:2(1). It is more common in Caucasians. Familial transmission can be seen and its relation with Gardner syndrome, Steinert disease, and sarcoidosis has been shown [9-11]. For about $50 \%$ of pilomatricomas are seen in the head and neck region and, less frequently, in the trunk, arms, and legs [5]. The size of lesion varies from 0.5 to $3 \mathrm{~cm}[12,13]$. The diagnosis can be made clinically before surgery in $40 \%$; however, definite diagnosis is made histologically. Recommended treatment method is the excision of lesion with surgery. Recurrence rate ranges between 2 and $6 \%$ following surgery. Here in we present a 40-year-old male case of pilomatricoma localized in the arm. We present our case due to its rare occurrence in the arm.

\section{Case Report}

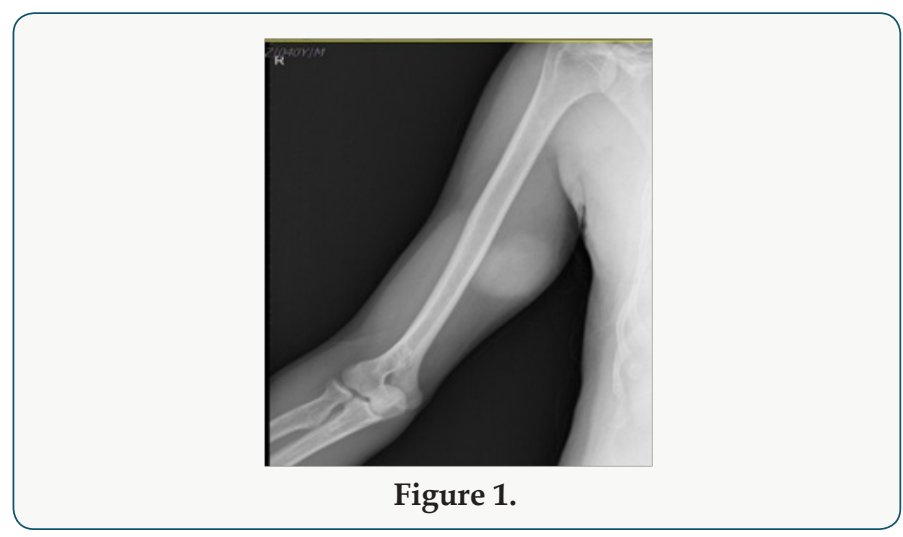

A 40-year-old man was admitted to our clinic with a palpable mass in the right arm. The mass which was first detected 10 months ago was painless, but was rapidly growing within the past three months. The patient history revealed no injury. On physical examination, there was swelling in 1/3 medium lateral of right arm. On palpation, a $5 \times 3 \mathrm{~cm}$ sized, growing outward from the skin, firm, painless, and mobile mass with smooth margins was observed. Neurological and vascular examination findings were normal. There was no other systemic pathology. Magnetic resonance imaging (MRI) showed an homogeneous lesion under the skin with smooth margins (Figures 1 \& 2). Needle biopsy was performed under local anaesthesia and biopsy result was compatible with pilomatricoma. 
Based on the biopsy result, the patient was operated under general anaesthesia and the mass with the skin was removed with marginal excision.

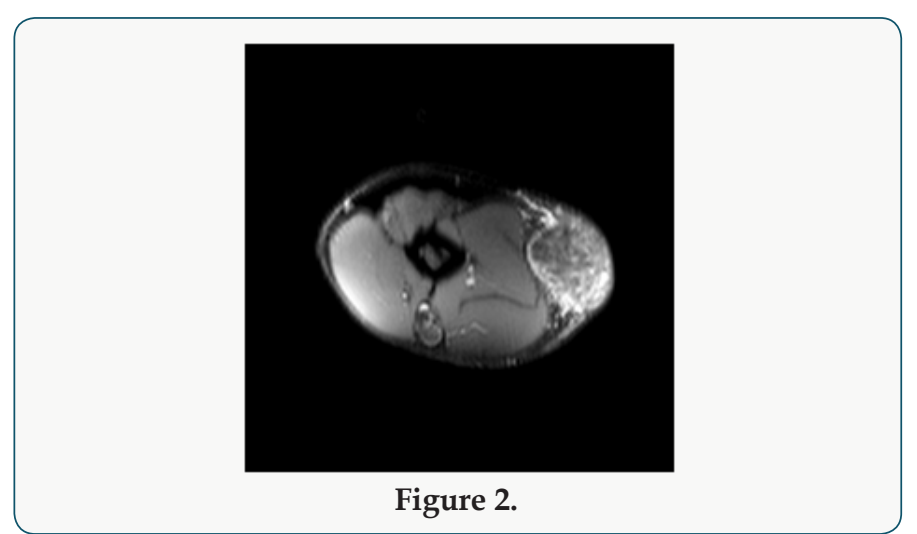

\section{Gross Examination}

The skin and under skin tissue was in $8 \times 5.3 \mathrm{~cm}$ size and $3 \mathrm{~cm}$ depth. There was a $0.4 \times 0.2 \mathrm{~cm}$ ulcerated area on the skin. Incision was made to under skin tissue. A yellow-brown coloured, firm mass was observed with a size of $6.5 \times 4.8 \times 4 \mathrm{~cm}$, which was $0.2 \mathrm{~cm}$ away from the base surgical border starting from the subcutaneous tissue (Figure 3). In the gross examination of excised tissue, a plurality of shadow cell layers in the soft tissue, widespread dystrophic calcification and foreign body giant cells surrounding them, a few number of mononuclear inflammatory cells, foreign body type granulation tissue consisting of vascular proliferation and fibrosis, and basaloid cells at one focus were seen. These findings were found to be compatible with a pilomatricoma (Figure 4).
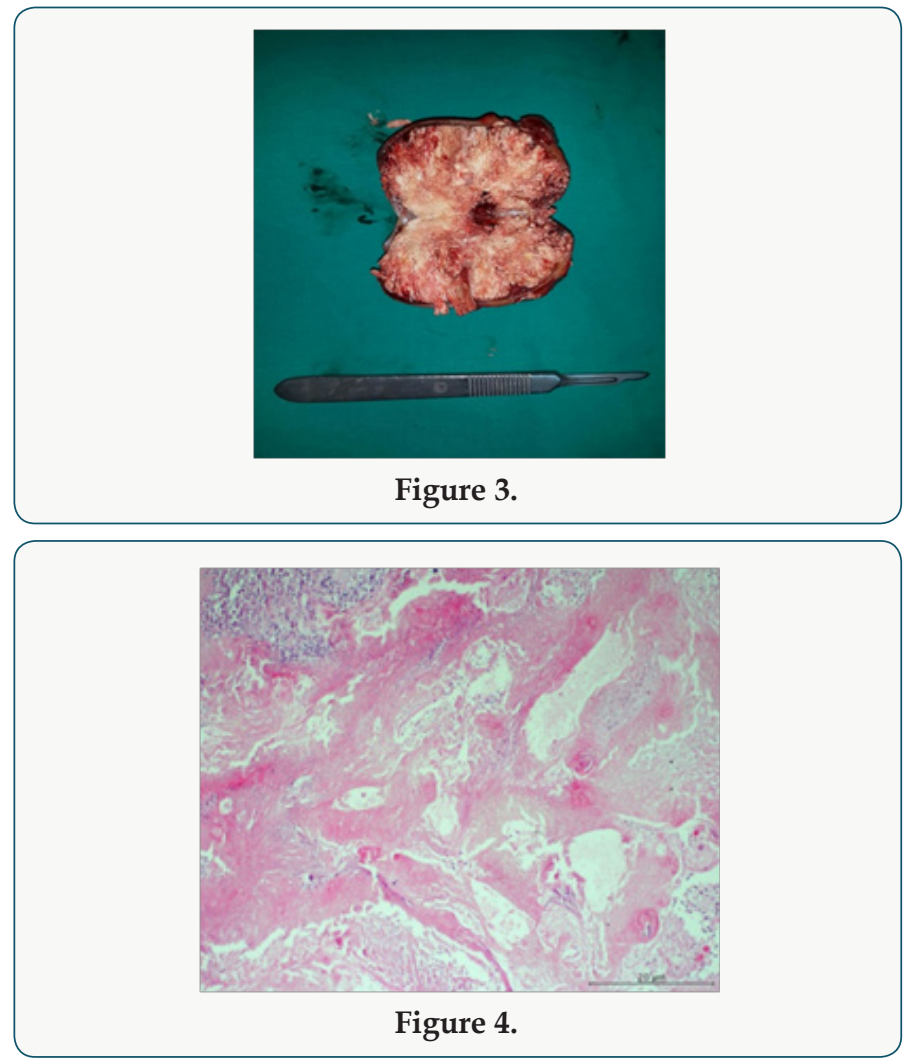

\section{Discussion}

A Pilomatricoma is a benign, typically firm, and slow growing tumour, which can present as a subcutaneous or dermal mass covered with normal skin tissue originating from hair follicle matrix. It has usually smooth margins with surrounding connective tissue, located in dermis and subcutaneous tissue without any connection with epidermis. The tumour is separated from epidermis with a band of fibrous tissue. This fibrous layer can form an illusion such as it adheres to the skin; however, there is no connection between tumour and epidermis, indeed $[14,15]$. Although it is well known that injury and infection can play an important role in the etiology, its exact etiology still remains to be elucidated. In addition, pilomatricomas have been reported to result from a pause in the cycle of hair follicles $[14,15]$.

Pilomatricoma shows a biphasic age distribution. Firstly, it affects children and adolescents with a ratio of $60 \%$; $40 \%$ of them are seen before 10 years of age and $60 \%$ of them can be seen before the age of 20 (12). Second, it reaches peak in the six and seventh decades of life [5-12]. A pilomatricoma is usually as a single nodule. Tumour size ranges from 0.5 to $3 \mathrm{~cm}$, however, $>15 \mathrm{~cm}$ tumours have been also reported $[12,13]$. In our case, the tumour size was $8 \mathrm{~cm}$. Tumour is usually asymptomatic and grows slowly within one month to one year. Clinically, a pilomatricoma can be seen as solitary, firm, painless, well-bordered, and dermal or subcutaneous masses. Lesions can be soft and cystic in the early period; however, they are typically firm and well-bordered in the late period. Furthermore, in cases where the lesion is extremely superficially localized, the overlying skin can show a dark shade of red, vivid blue or black colour change such as telangiectasia or haemangioma $[5,16]$. The diagnostic value of imaging studies is low for pilomatricomas. Due to their superficial location, radiological imaging cannot be routinely applied. Calcified foci can be detected with X-rays and intense posterior acoustic shadowing with well-defined, round hyper-echoic mass can be detected with ultrasonography [17].

In histopathological examination, pilomatricomas may show differences in various chronological stages. In the early stage, lesion usually appears as a cyst, which is covered with uniform basaloid cells originating from hair follicle matrix cells and eosinophilic cells with no nucleus which are mixed with keratin (shadow cells or ghost cells). Ghost cells are generated due to keratinization of basoloid cells and are diagnostic for pilomatricomas. Their number also increases as the lesion becomes older. The old lesions are firm. In microscopic examination, ghost cells, keratin, multi-nucleated giant cells, dystrophic calcification, and sometimes bone formation can be also seen. Atypical mitosis, central necrosis, infiltration of adjacent structures such as veins, skin and soft tissue, ulceration should bring to mind the malignant form, which is a very rare form of pilomatricomas, and the differential diagnosis should be made. To rule out invasive forms, a meticulous histological study should be performed, as it is possible, although it can be seen 
rarely. In malignant form, larger components of epithelial cells, undifferentiated sets of basaloid cells, atypical cells, blood vessels, and capsular tissue invasion can be seen $[8,18]$. The differential diagnosis may vary according to the localization of the tumour. In the differential diagnosis, dermoid cyst, parotid tumours in preauricular area, sebaceous cyst, calcified hematoma, brachial cleft, and giant cell tumours should be considered in the head and neck region, while epidermal inclusion cyst, lymphadenopathy, foreign body reactions and lipoma should be considered in other regions $[1,12]$.

Pilomatricomas do not show spontaneous regression and the treatment is simple excision. When it is totally removed, no recurrence is expected. If the tumour is close to the skin surface, it should be excised with overlying skin tissue in order to prevent residual tumour tissue. If tumour is adherent to the adjacent tissue and its borders are not well-defined, malignancy can be suspected. Making the excision with 1-2cm expansion can minimize the local recurrence risk $[9,13,17]$. In conclusion pilomatricomas are rare and benign skin tumours which can be usually seen in children and adolescents and are treated with surgical excision. Although its clinical diagnosis is difficult, palpation findings and the localization are suggestive. They are rarely localized in the extremities. Therefore, it should be kept in mind that if this tumour reaches big sizes, its recurrence risk will increase and it may transform into a malignant tumor. As a result, surgical planning after a careful evaluation of clinicohistopathological features is needed.

\section{References}

1. Brandner MD, Bunkis J (1986) Pilomatrixoma presenting as a parotid mass. Plast Reconstr Surg 78: 518-521.

2. Colver GB, Buxton PK (1988) Pilomatrixoma. An elusive diag. Int J Dermatol 27: 177-178.

3. Türkoğlu Z, Kavala M, Kocatürk E (2007) Pilomatriksoma. Göztepe Tip Dergisi 21: 77-78.
4. Doran F, Gümürdülü D, Uğuz A, Tuncer R (2000) Multipl Pilomatrikoma (Olgu Sunumu). Çukurova Üniversitesi Tıp Fakültesi Dergisi 25: 36-38.

5. Moehlenbeck FW (1973) Pilomatrixoma (calcifying epithelioma). A statistical study. Arch Dermatol 108(4): 532-534.

6. Ünlü Y, Karabağlı P, Kılıç H, Uğurluoğlu C (2007) Pilomatriks karsinoma. Selçuk Tip Dergisi 23: 35

7. Mayadağlı A, Yllmaz A, Tepetam H, Borataç Ü, Çepni K (2003) Pilomatriks karsinoma: Olgu sunumu. Kartal Eğitim ve Araştırma Hastanesi Tip Dergisi 14: 213-215.

8. Niedermeyer HP, Peris K, Höfler H (1996) Pilomatrix carcinoma with multiple visceral metastases. Report of a case. Cancer 77: 1311-1314.

9. Mc Culloch TA, Singh S, Cotton DW (1996) Pilomatrix carcinoma and multiple pilomatrixomas. Br J Dermatol 134: 368-371.

10. Aissaoui M, Doss N, Bouzaiene A (1995) Cas pour diagnostic (pilomatricome). Ann Dermatol Venereol 122: 797-798.

11. Urvoy M, Legall F, Toulemont PJ, Chevrant Breton J (1996) Multiple pilomatricoma. Apropos of a case. J Fr Ophtalmol 19: 464-466.

12. Lan MY, Lan MC, Ho CY, Li WY, Lin CZ (2003) Pilomatricoma of the head and neck: a retrospective review of 179 cases. Arch Otolaryngol Head Neck Surg 129(12): 1327-1330.

13. Mc Brien M, Victor T, Wolff AP (1988) Pathologic quiz case 2. Pilomatrixoma. Arch Otolaryngol Head Neck Surg 114: 1042-1045.

14. Kumar S (2008) Rapidly growing pilomatrixoma on eyebrow. Indian J Ophthalmol 56(1): 83-84.

15. Saussez S, Mahillon V, Blaivie C (2005) Aggressive pilomatrixoma of the infraauricular area: a case report. Auris Nasus Larynx 32(4): 407-410.

16. Yap EY, Hohberger GG, Bartley GB (1999) Pilomatrixoma of the eyelids and eyebrows in children and adolescents: Ophthal Plast Reconstr Surg 15: 185-189.

17. Duflo S, Nicollas R, Roman S, Magalon G, Triglia JM (1998) Pilomatrixoma of the head and neck in children: a study of 38 cases and a review of the literature. Arch Otolaryngol Head Neck Surg 124(11): 1239-1242.

18. Varlıklı O, Yıldız T, Çetin G, Yildirim M, Erdem M T (2013) Çocuklarda pilomatriksoma (kalsifiye epitelyoma)/Pilomatrixoma in children (calcifying epithelioma). Turkderm 47(2): 84.

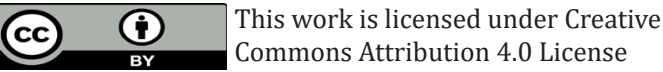

To Submit Your Article Click Here: Submit Article

DOI: 10.32474/OAJOM.2018.01.000118

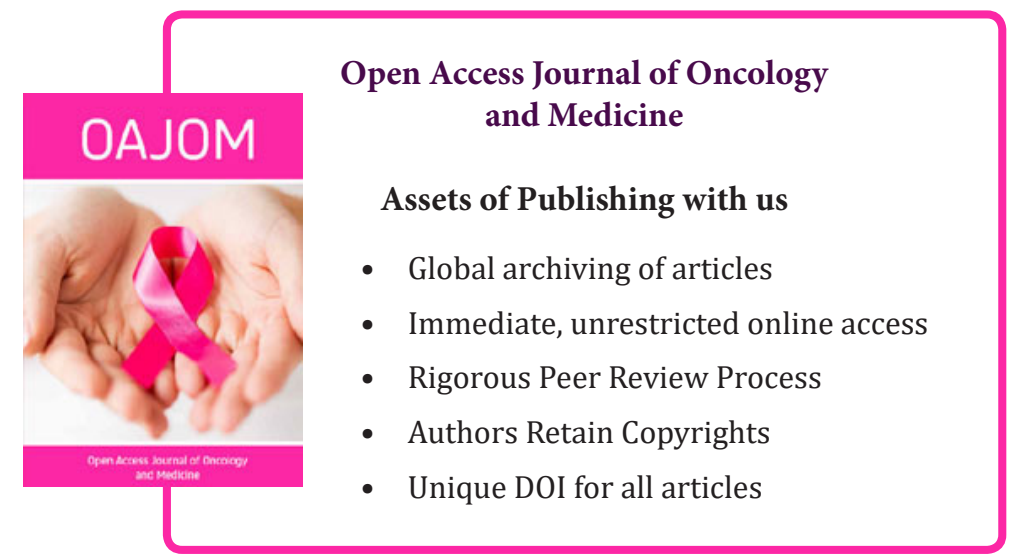

